\title{
Creation and Elaboration of Problem Space Depending on Students' Attitudes toward the Task and Thinking Skills
}

\author{
Kyungjin Kim* \\ Belin-Blank Center for Gifted Education and Talent Development, College of Education, \\ The University of lowa, IA 52242-0454, U.S.
}

\section{학생의 과제에 대한 태도와 사고력에 따른 문제공간의 형성과 정교화}

\author{
김 경 진* \\ 아이오아 대학 교육학부 벨린 블랭크 영재센터, 미국 아이오아주 52242-0454
}

\begin{abstract}
Inquiry has been emphasized in science classrooms, but the problems shown in the inquiry are somewhat different with ones that students usually meet and experience in everyday life. The purpose of this study is to investigate how attitudes toward the task and thinking skills affect students' problem solving process, especially, the way of creating a problem space and elaborating problem solving strategies when they have little schema. The difference in students' problem solving strategies of Lego Robotics class, one of the summer programs for $4^{\text {th }}-6^{\text {th }}$ grade gifted students, which is new to them, was investigated. The results are as follows: (1) The difference in attitudes toward the task, or selection and identification of the missions, and the perception of operators, affected creating a different problem space. (2) Different level of thinking skills, or analytical and flexible thinking, efficient elaborative skill, and application of schema affected a different level of elaboration of the problem space and resulted in asuccess rate of problem solving. (3) Different initial problem space resulted in different problem solving strategies. But without thinking skills, students could not elaborate problem solving strategies efficiently. Several instructional recommendations to promote scientific inquiry were suggested based on the results.
\end{abstract}

Keywords: problem solving strategies, problem space, thinking skills, attitudes toward the task, gifted students

요 약: 탐구는 학교과학에서 지속적으로 강조되어 왔다. 하지만 학교에서 주어지는 문제는 학생들이 일상생활에서 경험 하고 부딪치는 문제들과는 여러 면에서 다르다. 본 연구의 목적은 학생들이 문제에 대한 인지도식을 거의 갖고 있지 않을 때, 과제에 대한 태도와 사고력이 문제해결과정, 특히, 문제공간의 형성과 정교화에 어떻게 영향을 미치는지를 알 아보는 것이다. 이를 위하여 연구자는 미국의 한 영재센터 여름방학 프로그램 중 4-6학년 영재학생 대상 레고 로봇 수 업'에 참여한 학생들의 문제해결전략을 추적하였다. 결과는 다음과 같다. (1) 과제의 선택과 파악방법, 작동자에 대한 인식의 차이 등 과제에 대한 태도는 서로 다른 문제공간을 형성하게 하였다. (2) 분석적 사고, 융통성, 효율적인 정교화 기술, 기존 인지도식의 적용 등의 사고력의 수준 차이는 문제공간의 정교화 차이와 문제해결의 성공여부로 이어졌다. (3) 초기의 문제공간의 차이는 문제해결전략의 형성 차이를 가져왔지만, 사고력 없이는 호과적인 문제해결전략의 정교 화가 이루어지지 못하였다. 마지막으로, 위의 결과를 바탕으로 과학탐구를 증진시킬 몇 가지 사항이 제안되었다.

주요어: 문제해결전략, 문제공간, 사고력, 과제에 대한 태도, 영재학생

\section{Introduction}

Inquiry has been emphasized in science classroom for several reasons. Students can gain new data to

*Corresponding author: kjkim@kordi.re.kr

Tel: $82-31-400-7752$

Fax: 82-31-406-6925 change their ideas or deepen their understanding of important scientific principles through it. Students can learn about the world. Although they rarely discover knowledge that is new to humankind, current research indicates that students engaged in inquiry build knowledge new to themselves. They also develop important abilities such as reasoning, careful 
observing, and logical analysis (Minstrell, 1989; Rosebery et al., 1992).

But, inquiries in school are somewhat different with ones that students usually experience in everyday life. The problems are not usually related to one specific domain. To solve these problems, students need different kinds of knowledge, or schemata in several domains acquired through their experiences inside and outside of school. Students have to combine, reorganize them through integration to find a solution. They need to know how to apply what they already know to their actual situations. Besides, students have to decide what they need to learn when they think their knowledge is not enough to solve their problems. If we want to improve student's inquiry skills, we should understand how students approach a solution in those contexts, especially, from the point of view of problem solving, not just inquiry in school.

Problem solving is an investigative task whereby the solver explores the solution path to reach a goal from given information. Problem solving needs thinking skills. Students should plan, monitor, and evaluate their strategy. Creativity, inductive reasoning, deductive reasoning, spatial visualization, and other thinking skills are required for creating strategy and analyzing the result (Stemberg, 1985). Some Authors argue that such factors as attitudes and constraints of the task may determine problem solving representation and solution activity (Voss et al., 1983; Schoenfeld, 1983). Problem solving strategy is a technique that may not guarantee a solution, but serves as a guide in the problem-solving process (Mayer, 1983). It reflects how students create a problem space and how they approach a solution using thinking skills.

Main interest in this study is to investigate that how those above factors, thinking skills and attitudes of the task, affect students' problem solving process, especially, the way of creating a problem space and elaborating problem solving strategies when they have little schema. The question addressed is what main factors can explain the difference of students' achievement when they try to solve a problem at the same condition, having little schema to a problem and how those factors drive students the way of approaching their solution.

In this study, the difference in students' problem solving strategies affecting their achievements in Lego Robotics class, one of summer programs for $4^{\text {th }}-6^{\text {th }}$ grade gifted students which is new to them, was investigated. And how thinking skills and attitudes of the task influenced students' problem solving process was also examined.

\section{Problem Solving Strategies, Problem Space, and Attitude}

Problem solving is a learning that bridges the gap between the learner's existing knowledge and the solution to the problem through transformation of information by analysis, synthesis, hypotheses, formulation, testing, rearrangement, recombination, translation, and integration (Ausubel, 1968). Most research on problem solving has been focusing on how people apply their schema to solve the problem (Gick, 1986). Especially, they have been trying to find out how schema (learning) connects with strategy (problem solving process). Comparison between 'High $\mathrm{A}$ ' and 'Low A' (comparison between the people who have much schema related to problems and those who have not) has been researched for this purpose. Dhillon (1998) summarized commonly used strategies in problem solving: analogy, brainstorming, envisioning, forward strategy, generate and test, heuristic search, means-ends analysis, problem abstraction, problem decomposition, working backward. he mentioned that most solvers use a combination of these problemsolving strategies and the strategies used depend on the amount of factual and procedural information available and the experience of the problem solver.

Pizzini et al. (1989) mentioned the importance of creating a problem space, which is a mental representation of the problem that includes a description of objects, the initial problem situation, the necessary operator(s) to solve the problem and an idea of the goal or final state. As to Goldschmidt (1997), problem space continuously changes depending on 


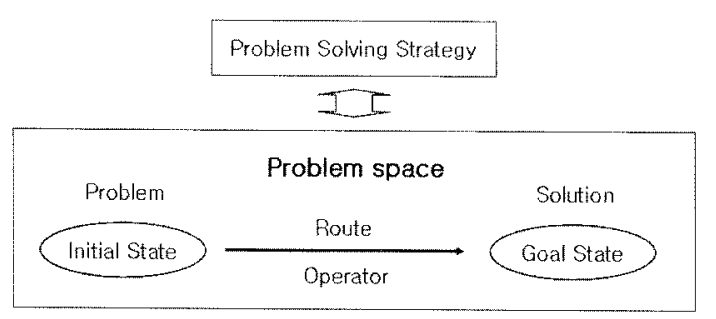

Fig. 1. The interaction between problem solving strategy and problem space.

solver's definition of a problem and operators coming with a number of functions, e.g. evaluation, transformation, and problem-specific heuristic from an initial state through intermediate states to a goal state. In summary, understanding the problem construct a problem space and determine the problem solving procedure used to explore and solve it. Problem solving strategy interacts with problem space and change the approach to a solution, e.g. route, operator, and so on. If the problem is re-identified, the problem space will be changed and as a result, problem solving strategy will be, either (Fig. 1).

This process needs thinking skills. Sternberg (1985) classified thinking skills into three groups: metacomponents, performance components, and knowledge acquisition components. Meta-components are used to plan, monitor and evaluate. Performance components are used to execute the meta-components and provide feedback, and vary by discipline. Knowledge acquisition processes are used to learn concepts or procedures.

Problem itself is another thing we should consider in problem solving process. In reality, scientists choose their research topic through their research or reading articles, or discussion with other scientists. They select to solve one or several topics among many problems they meet. Students choose one or several problems they want to solve among things they meet in everyday life. They identify the problems based on their experience and concept and establish their problem solving strategies using thinking skills. If they realize they don't have enough schemata to solve it, they need to determine what schemata they have to learn and how to do it for the next step. If we want to know how the students solve the problems, we should give them a chance to choose the problems they want to solve, trace how they create a problem space, elaborate problem solving strategies, and analyze their processes.

Research on effective thinking and intelligent behavior indicates that there are identifiable characteristics of effective thinkers and Costa mentioned the list of 16 habits of mind which provide the dispositions necessary to do the skillful thinking: persisting when the solution to a problem is not readily apparent, managing impulsivity, Listening to others with understanding and empathy, thinking flexibly, metacognition, striving for accuracy and precision, asking questions and posing problems, applying past knowledge to new situations, thinking and communicating with clarity and precision, gathering data through all senses, creating, imaging, innovating, responding with wonderment and awe, taking responsible risks, finding humor, thinking interdependently, and remaining open to continuous learning (Costa, 2003).

Then, what thinking skills and attitudes and how do they affect students' problem solving process especially, the way of creating a problem space and elaborating problem solving strategies, and result in different achievements?

The purpose of this study is to investigate the students' problem solving strategies when they are encouraged to solve the problems where they have not much schema in working with. In this study, I traced the problem solving strategies of gifted students participating in Lego Robotics class, one of the $4^{\text {th }}-6^{\text {th }}$ grade summer programs in U.S. and compare their strategies in between 'High A' and 'Low A' groups.

\section{Lego Robotics Class}

\section{The context of Lego Robotics class}

FIRST LEGO League (FLL) is an international program for children ages 9-14 (9-16 outside of the U.S. and Canada). Its program is for engaging students in playful and meaningful learning while helping them to discover the fun in science and 
technology. Students are expected to build and experiment, creating ideas, solving problems, and overcoming obstacles and to shape a positive perception of science and technology and motivate them to learn through this program.

One of main parts in this program is a hands-on, interactive robot game. Teams design, build, program, and test autonomous robots that must perform a series of tasks, or missions. In 2006, Students designed, built, and programmed for robots to complete missions using model related to Nano-technology (Lego League Homepage).

Lego Robotics class, one of summer programs at center for the gifted and talented in one University in U.S. for $4^{\text {th }}-6^{\text {th }}$ grade gifted students in 2007 is for introducing gifted students who are new, but interested in robots to FLL, encouraging them to explore science and technology, and challenging them to develop their problem solving skills. Students experienced a same robot game and a project of FLL in 2006, but used a new robot model, Mindstorms NXT Robot in 2007. Students were expected to learn about the nano world as they designed, built, and programmed a robot to solve the missions for two weeks, 10 days, 3 hours a day, total 30 hours. In this study, robot game was a main focus for tracing students' problem solving strategies.

Students were required to put a robot together, learn about programming for a robot and the principle of sensors, and test them before starting their missions. Students decided their speed of learning and programs they want to learn through a video trainer as selfdirected learners. Because of short time in Lego Robotics class rather than FLL, they chose several missions they want to complete among total nine missions. After putting the robot together and learning through a video trainer, they are expected to decide missions and sensors for them. They created their strategies and made attachment tools for their missions. At the same time, students were expected to research through books, or resources, or websites and prepare for a presentation. The teacher's role was a facilitator, not an instructor. She guided directions through asking questions only when students needed help.

The number of the students in this class in 2007 was 19 . Seven $4^{\text {th }}$, eight $5^{\text {th }}$, and four $6^{\text {th }}$ grade gifted students registered. Among them, two $4^{\text {th }}$ grade students were girls and others were boys. Five teams, two $4^{\text {th }}$, two $5^{\text {th }}$ and one $6^{\text {th }}$ grade teams consisting of three or four students were built depending on their grades, and each team was provided two Mindstorms NXT Robots. Therefore, two students were expected to cooperate with each other to build, program and test a robot independently from other members in their team.

In addition, students could share any ideas with other teams and develop their strategies from other team's behaviors. All students could watch other team's strategies, tools, and their success or failure. They could apply similar strategies or tools which other teams already succeeded with. Students could also give advices to other teams or help them make tools or program for a robot.

This class was selected to investigate students' problem solving strategies for three reasons. First, Lego Robot was new to all participants, even though they were familiar with Lego. Therefore, this study could carry out on the assumption that they had little schema to this class and they would start at the same level of knowledge. The second, all the participants chose this program because they liked science and Lego very much. They had motivation to solve their missions eagerly. The third, all participants were identified as gifted students in their school, or took several programs for gifted inside and outside of school. Students' clear expression of thinking were expected.

\section{Missions in Lego Robotics class}

Figure 2 shows the missions in the Lego Robotics class. All the missions were based on Nanotechnology model made of Lego materials or images. Mission 1, for example, is to lift the truck by a thin cable of carbon nanotubes. The robot must move the truck onto the lift frame and activate the lift. This 


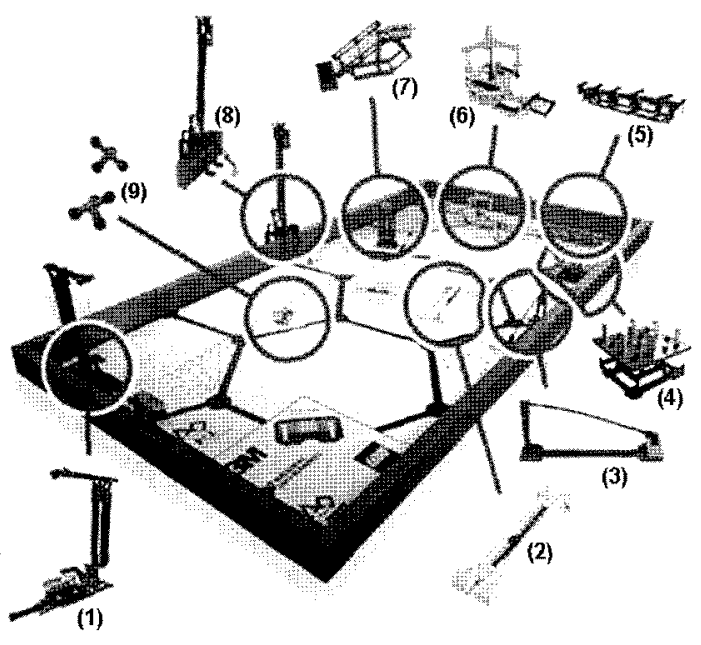

Fig. 2. Missions in Lego Robotics class.

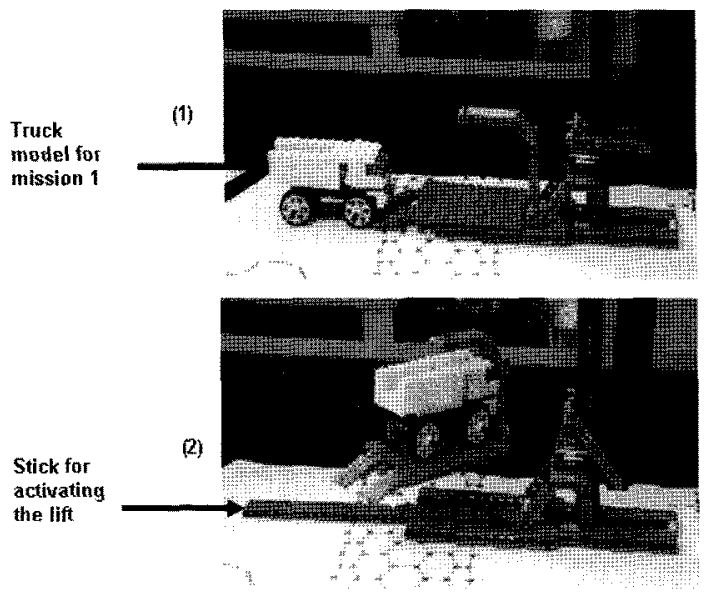

Fig. 3. Mission 1. (1) Before starting the mission and (2) after completing the mission.

mission had two parts. One was to push the truck and the other was to push the long stick so that the lift frame would be activated (Fig. 3).

Main challenge for all missions was that the navigation of the robot had some error. Even if students made a program for going straight, it drifted. As the longer the distance the robot should go, the bigger the error existed. Students had to find the way how the robot reached the goal station with the least errors before it started the missions. Another challenge was time. Students needed to complete their missions within 2 minutes and 30 seconds.

In summary, students needed to create strategies for

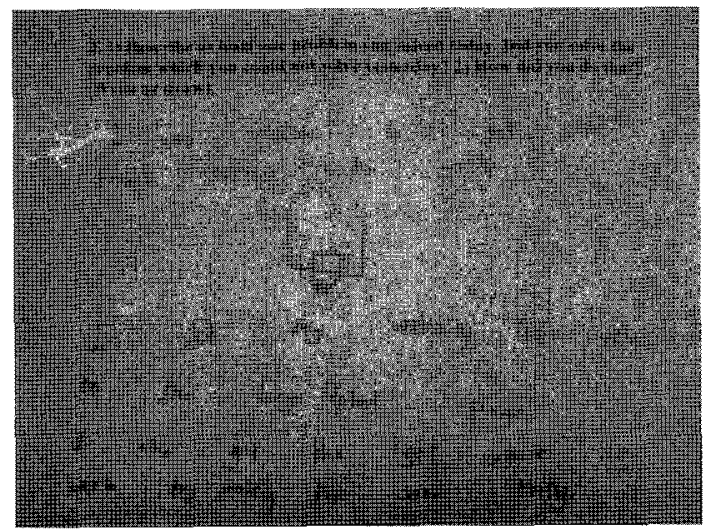

Fig. 4. Journaling from group 1.

reaching the goal station, make appropriate attachment tools and program for completing their missions in limited time.

\section{Data collection and analysis}

It is essential to observe students' behaviors and how they reflect their strategies to trace the students' problem solving strategies. Videotaping is the good method for that. Every time students tested their robots on the board, Author videotaped and asked them what they changed and the reason. They could change the program, attachment tools, paths to the goal station, or any combination of those. Field note of observing the class was used for understanding the process of the class and recording the progress of each team's works. Students were supposed to write their journals everyday during the class. At the start of the class, students wrote what challenges they faced and what strategies they planned for solving their problems. At the end of the class, they reflected their progress and wrote what problems they solved or what problems they could not solve and the reason (Fig. 4).

Journaling was for students to reflect their problem solving strategies and stimulate to develop them. Because most students were boys and did not like to write, journaling was an assistance tool for understanding their progress. Instead, author interviewed each group about their perception about their progress and how they changed their strategies and the reason on 
occasion. In addition, videotape was analyzed roughly everyday and interviewed students whenever Author could not understand their behavior or strategies. Interviews and videotaping were the main methods and field note and journaling were the assistant methods of tracing students' problem solving strategies.

There were five teams. Each team of four students divided into two groups of two which could work with one robot each. The exception was one 4 th grade group that had three members who worked with one robot. Total 9 groups were built and each group could work independently. The main problem in this study was the different speed of group's working in learning and putting a robot together before they started their missions. I excluded groups whose speed of putting a robot together and learning through a video trainer was too slow. Only the groups who were ready for starting their missions at the similar time and tried at least two missions were considered. One $4^{\text {th }}$, three $5^{\text {th }}$, and one $6^{\text {th }}$ grade, total five groups were selected.

Interviews were translated. Each group's works were rearranged from videotaping and interviews and made the 1st analysis note. The note included the whole process of five group's problem solving and my analysis of their behaviors and thoughts. It also included the reason why they selected their missions, the way of reflecting on their works, and the way of changing their strategies or tools from that. Field note and journaling were used to assess the reliability of the $1^{\text {st }}$ analysis note. Author focused on and compared the characteristics of their elaboration of problem solving strategies when they succeeded or failed in their missions. Table 1 shows the information of five groups, the missions they tried, and their success. The names of groups and students are not real.

Among these groups, author divided into High
Achievement ('High A') and Low Achievement ('Low $\left.A^{\prime}\right)$ groups depending on the accomplishments of their missions at the end of this course. 'High A' groups were defined as those who tried and succeeded in at least two missions during the class or competition. 'Low A' groups were defined as those who tried at least two missions, but succeeded in only one or could not in any mission. The 'High A' groups were three $5^{\text {th }}$ grade groups and the 'Low A' groups were one $4^{\text {th }}$ and one $6^{\text {th }}$ grade group (Table 1). Based on the results of tracing each group's creation and elaboration of problem spaces, author elicited what factors, especially, what attitudes of the task and thinking skills could explain the difference of the accomplishments on their missions, or and how those factors affected their problem solving processes between 'High $A$ ' and 'Low A' groups.

\section{Findings}

The problem solving strategies between 'High $A$ ' and 'Low $A$ ' groups were different in the way of creating a problem space and elaborating it.

\section{The way of creating a problem space}

Students created different problem spaces in the way of choosing missions, identifying them, and perceiving operators, or sensors and programming to complete their missions (Table 2). Students seemed to choose missions which they thought easy to solve and to use same attachment tools or same sensors for different ones.

Those are pushing an object and pretty simple'High $A$ ' group 3 .

We chose missions because those two missions

Table 1. Description of groups on Lego Robotics class

\begin{tabular}{lcccc}
\hline Group & Student name & grade & $\begin{array}{c}\text { Missions they tried } \\
\text { to solve }\end{array}$ & $\begin{array}{c}\text { Missions they } \\
\text { succeeded in }\end{array}$ \\
\hline High Achievement ('High A') group 1 & Honghyun and Paul & $5^{\text {th }}$ & $(3)$, (8), and (5) & $(3),(8)$ \\
High Achievement ('High A') group 2 & Mike and Nick & $5^{\text {th }}$ & $(1)$ and (8) & $(1),(8)$ \\
High Achievement ('High A') group 3 & Roger and Jay & $5^{\text {th }}$ & $(3)$, (5), and (7) & $(5),(7)$ \\
Low Achievement ('Low A') group 1 & Jonathan and Brad & $6^{\text {th }}$ & $(1)$ and (8) & $(1)$ \\
Low Achievement ('Low A') group 2 & Kang, Adam and Rob & $4^{\text {th }}$ & $(1),(3),(8)$, and (9) & None \\
\hline
\end{tabular}


are to push things'-'High A' group 2.06/18/2007.

But the difference between 'High A' and 'Low A' group were whether they took risks for complicate trials for high score, or were willing to learn difficult things for increasing the success, or not. 'High A' group 1 chose missions near the black line instead of choosing easy looking missions for going to the goal station (Fig. 2). They saw other kids' robots move drift. They thought that If they could program for a light sensor so that the robot followed the black line, it could reach the goal without drift errors. So, it was important for them to choose missions where they could use light sensor. Light sensor was the most difficult concept among all sensors and it was not easy for them to learn it. But they wanted to learn and spent much time on understanding the principle of it.

'Low A' groups also chose missions they thought simple and easy to solve, but they wanted easy strategies or tools. 'Low A' group 2 wanted to follow the same tool or strategies of other groups after they watched other groups' work. They tried mission (1), (3), (8), and (9) which other groups already succeeded in. But instead of taking risks, making complicate programs and sticking on their missions for success, they easily moved to another mission whenever they thought it more difficult than their expectation.

All groups examined the problems at first. They created the initial idea or strategies by moving their robot by hand and discussed it. 'High A' groups tried to figure out what mission was exactly before they started a mission. It took long for them to discuss the mission itself or what sensors they could use for it. They examined all the hypotheses or possibilities. They discussed the way to reduce the drift errors and get to the goal station, and what attachment tools they needed.

On the other hand, it did not take long for 'Low A' groups to consider problems itself. They wanted to solve their problems quickly. They selected simplest ways and programs rather than considering accuracy. They tried their strategies first and elaborated the program only after watching the result rather than tried to create an elaborated strategy and program considering all the possible cases they could think for accuracy.

The difference in identification of the problems, or missions between 'High A' and 'Low A' groups resulted in the contrast in perception of the operators, or sensors and programming.

'High A' groups considered the sensor or programming, i.e. operators seriously. They perceived the importance of schemata they had to learn for carrying out their missions. Before they determined which mission they wanted to complete, they tested all sensors, discussed the possibility of using each sensor, and spent time on acquiring the schemata, or operators.

'High A' group 1 started their missions later rather than other groups. They spent much time on learning about the sensors. They watched a video trainer, followed the direction in detail, and learned principles of different sensors and how to program. They tested the demo programs to make sure their learning. Once they mastered it, the speed of their working was accelerated. All the robot had to do was to follow the black line for getting to the goal stations. They didn't have to consider the drift errors which other groups were concerned the most (Fig. 5).

Meanwhile, 'Low A' groups wanted to solve their problems quickly rather than explore the possibility of using different sensors. They underestimated the prerequisite of schemata. 'Low A' group 1 did not watch a video trainer seriously and did not test all the sensors. They said light sensor was too difficult for them to understand. But they did not even try the

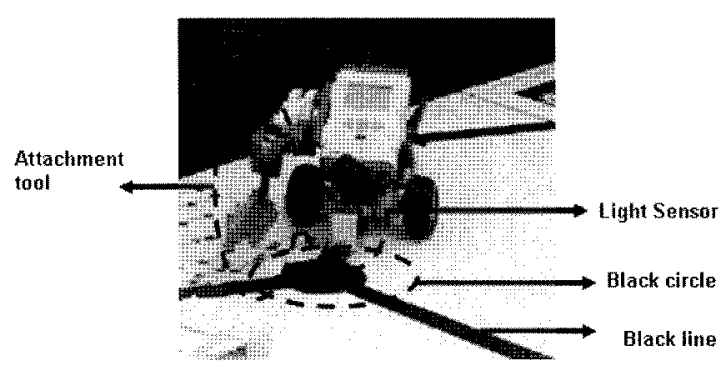

Fig. 5. 'High A' group 1's attachment tools for mission 3. 
Table. 2. The way of creating a problem space

\begin{tabular}{|c|c|c|}
\hline & 'High A' group & Low A' group \\
\hline \multirow[b]{2}{*}{ Missions chosen } & \multicolumn{2}{|c|}{$\begin{array}{l}\text { Students chose missions which they thought easy to solve and to use same attachment tools or same } \\
\text { sensors for different missions. }\end{array}$} \\
\hline & $\begin{array}{l}\text { Students took risks for complicate trials for high } \\
\text { score, or were willing to learn difficult things for } \\
\text { increasing the success }\end{array}$ & $\begin{array}{l}\text { Students wanted easy strategies or tools. They } \\
\text { wanted to follow the same tool or strategies of } \\
\text { other groups' successful works. }\end{array}$ \\
\hline $\begin{array}{l}\text { Identification of problem, or } \\
\text { initial problem situation }\end{array}$ & $\begin{array}{l}\text { It took long for students to discuss the mission } \\
\text { itself or what sensors they could use for it. } \\
\text { Students tried to figure out what mission was } \\
\text { exactly before they started a mission. } \\
\text { Students examined all the hypotheses or } \\
\text { possibilities. }\end{array}$ & $\begin{array}{l}\text { It did not take long for students to consider } \\
\text { problems itself. } \\
\text { Students selected simplest ways and programs } \\
\text { rather than considering accuracy } \\
\text { Students tried their strategies first and elaborated } \\
\text { the program only after watching the result before } \\
\text { considering all the possible cases for accuracy }\end{array}$ \\
\hline $\begin{array}{l}\text { Perception of operators, or } \\
\text { sensors and programming }\end{array}$ & $\begin{array}{l}\text { Students considered the sensor or programming, } \\
\text { i.e. operators seriously. } \\
\text { - Before students determined which mission they } \\
\text { wanted, they tested all sensors and programming. } \\
\text { Students spent enough time on acquiring the } \\
\text { schemata, or operators. }\end{array}$ & $\begin{array}{l}\text { Students did not watch a video trainer seriously } \\
\text { and did not even try the demo program for some } \\
\text { sensors. } \\
\text { Students wanted to solve their problems quickly } \\
\text { rather than explore the possibility of using } \\
\text { different sensors. } \\
\text { Students started on the mission straight right after } \\
\text { learning simple programs. }\end{array}$ \\
\hline
\end{tabular}

demo program. After learning simple programs, or going straight and backward, they started on the mission straight.

\section{Elaborating a problem space: Thinking skills affecting the problem solving strategies}

'High A' and 'Low A' groups elaborated problem spaces differently. Analytical and flexible thinking and capability of elaborating strategies efficiently and applying schema not learned from Lego Robotics class to strategies affected them (Table 3).

'High A' groups could figure out their problems of their strategies, or attachment tools, or program very quickly from reflection and created new strategy to solve the problem.

When 'High A' group 1 tried to program for robot to follow the black line for mission (3), the main challenge was that black line had branch roads and the robot should be programmed for choosing left or right side on every branch road for reaching the goal stations (Fig. 5).

They programmed to turn right when the robot meet the branch roads, but the robot could not search a right line and circled instead. Honghyun and Paul looked confused at first.

But, suddenly, Honghyun said, "I got it!. Look!

Black circle (black circle is the center of branch

roads) is too thick, so light sensor can not sense

the opposite line of the circle. We should reprogram it."

They modified the program for robot to follow the right line of black road before it met branch road and succeeded in it./ 06/15/2007

On the other hand, 'Low A' groups could not figure out what the problem was exactly in their strategies. They had much difficulty in finding whether their problem was from program or attachment tools or the strategies. During working with mission (1), 'Low A' group 2 had much difficulty in solving their problem. To complete this mission, the robot must move the truck onto the lift frame and activate the lift (Fig. 3). They made two attachment pushing tools like other groups. Students should consider the distance between the truck and stick for activating the lift a frame to complete the misssion. 'Low A' group 2's work on this mission failed continuously. The distance between two attachment tools was not appropriate. Before pushing the truck completely, the robot pushed the 
stick to activate the lift frame and the truck was fallen. They could not realize what their problem was. Instead of correcting their attachment tools, they just only reprogrammed because they thought their program was not correct.

'High A' groups were very flexible in elaborating their strategies and attachment tools. 'High A' group 2 tried the same pushing tool used in mission (1) for mission (8) at first. They added another push tool for mission (8) later because they realized the robot should push the lower area for it. This new tool could be folded not to be an obstacle when the robot worked with mission (1) (Fig. 6). 'Low A' groups also changed their strategies or tools as 'High A' groups did. But their thinking was limited and not enough efficient to solve their problems. As they sometimes did not know what their problems were in their strategy, they seemed to have difficulty in being flexible in changing their previous strategies.

\section{Conclusions and Implications}

The problem solving strategies between 'High $A$ ' (High achievement) and 'Low A' (Low achievement) groups were different in the way of creating a

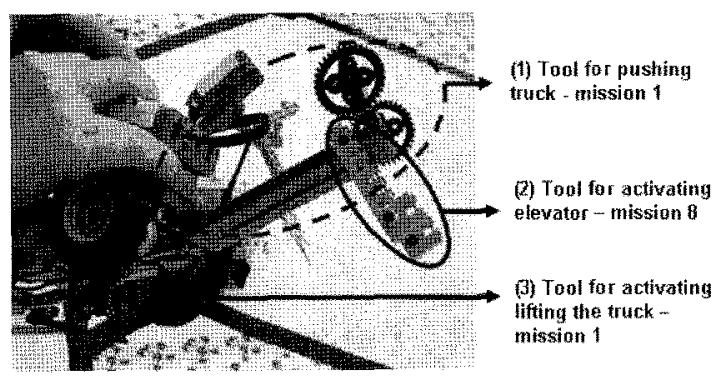

Fig. 6. 'High A' group 2's attachment tools. (2) and (3) can be folded.

problem space and elaborating it. The difference in attitudes toward the task between each group, or selection and identification of the missions, and perception of operators, affected creating a different problem space. On the other hand, different level of thinking skills, or analytical and flexible thinking, efficient elaborative skill, and application of schema affected different level of elaboration of the problem space and as a result, success rate of problem solving.

Different initial problem space resulted in different problem solving strategies. So creating an appropriate problem space was very important as some Authors argued (Goldschmidt, 1997; Pizzini, et al., 1989). But without thinking skills, students could not elaborate problem solving strategies efficiently and complete

Table 3. Elaborating a problem space: Reflection on and elaborating problem solving strategies

\begin{tabular}{|c|c|c|}
\hline & 'High A' group & 'Low A' grous \\
\hline Analytical thinking & $\begin{array}{l}\text { Students figured out their problems of their } \\
\text { strategies, or attachment tools, or program very } \\
\text { quickly from reflection and created new strategy. }\end{array}$ & $\begin{array}{l}\text { Sudents could not figure out what the problem } \\
\text { was exactly in their strategies. They had much } \\
\text { difficulty in finding whether their problem was } \\
\text { from program or attachment toots or the } \\
\text { strategies. }\end{array}$ \\
\hline Flexible thinking & $\begin{array}{l}\text { Students were very flexible in elaborating their } \\
\text { strategies and attachment tools. } \\
\text { - Students modified or added tools into another } \\
\text { mission easily }\end{array}$ & $\begin{array}{l}\text { Sudents changed their strategies or tools as 'High } \\
\text { A' groups did. But their thinking was limited and } \\
\text { not enough efficient to solve their problems. } \\
\text { - Because students sometmes did not know what } \\
\text { their problems were in their strategy, they seened } \\
\text { to have difficulty in being flexible in changing } \\
\text { their previous strategies. }\end{array}$ \\
\hline $\begin{array}{l}\text { Efficient elaboration of } \\
\text { strategies or tools }\end{array}$ & $\begin{array}{l}\text { Students atachment tools became stable and } \\
\text { stronger. } \\
\text { - Students covered or found the way to minimize } \\
\text { the error }\end{array}$ & $\begin{array}{l}\text { Students strategies were not consistent and } \\
\text { efficient. } \\
\text { - Students moved to another mission quickly } \\
\text { whenever they met some challenges and continue } \\
\text { to fail rather than kept concentrating on it and } \\
\text { finding the solution. }\end{array}$ \\
\hline $\begin{array}{l}\text { Application of schema not } \\
\text { learned from Lego robotics class }\end{array}$ & $\begin{array}{l}\text { Sudents applied science or mathenatical concepts } \\
\text { from their experiences to establish strategies }\end{array}$ & $\begin{array}{l}\text {-Applications of schemata from students" } \\
\text { experiences were not observed }\end{array}$ \\
\hline
\end{tabular}


their missions. 'High A' groups completed their missions through creating a problem space successfully with active attitudes toward them and elaborating the problem space efficiently using thinking skills. They tested and concretized each hypothesis through reflection, and investigated other possibilities to raise the rate of success consistently. They also persisted in their missions and elaborated their strategies, attachment tools, and programs until they made sure they completed their missions.

One of the main focus on this study is to find out how students approach the solution and how they perceive schema which they need to learn. In Lego Robotics class, operators, or sensor and program are very important schema which students should acquire to solve their missions. 'High A' group perceived the importance of schemata, or operators. They spent much time on acquiring the schema, or knowledge of operators. Meanwhile, 'Low A' groups wanted to solve their problems quickly rather than explore the possibility of using different sensors and learned complicate programming. They underestimated the prerequisite of schema. It resulted in common failure of establishing appropriate problem solving strategies when they met the challenge, because they didn't know how to modify program or how to use appropriate sensors.

Above results imply several instructional guides to promote scientific inquiry. First, Ausubel (1968) mentioned that some students are more successful than others in learning science and this may be due to differences in the way students learn-whether it is meaningful or rote learning. During creating a problem space, 'High $A$ ' groups perceived operators seriously and spending much time on acquiring them. It means that they recognized the importance of the operators as prerequisite knowledge applying to their mission and made efforts for meaningful learning. Although 'Low A' groups had motivation and interest at the task, they overlooked the importance of operators. In science class, If teachers can not relate to new knowledge and future application effectively inside and outside of school, students don't have any reason to focus on acquiring new knowledge, or meaningful learning.

Second, scientific inquiry requires the conceptual identification of assumption, use of critical and logical thinking, and consideration of alternative explanations if it is to be effectively used as a method for solving problems (Thomson and Stewart, 2003). In this study, thinking skills like analytical thinking, flexible thinking, application of past knowledge to new situation, and creating and elaborating strategies were essential to solve the problem. 'High A' groups were good at these thinking skills. Analytical thinking was prerequisite condition in creating and elaborating strategies. Without it, students could not find the problem in their strategies. Only after they could figure out the problem, they could start thinking how to solve it. Flexible thinking and application of past knowledge to new situation were essential to elaborate strategies.

Attitudes toward the subject is also important as well as thinking skills for meaningful learning. Students' attitudes toward the task played a main role in creating problem spaces, problem solving strategies, and therefore their success in this study. They include the perception about the task, tendency of taking risks, management of impulsiveness, persistence, inquisitiveness, and striving for accuracy and precision. Costa (2003) insisted that in order to engage skillfully in problem solving, decision making or knowledge generation, people must possess the inclination to decrease impulsiveness, display empathy, and be inquisitive and persistent. She identified them as the habits of mind of skillful thinking.

As Above mentioned, 'High A' (High Achievement) groups were defined as those who succeeded in at least two missions, while 'Low A' (Low Achievement) groups were those who succeeded in only one or could not in any mission. 'High A' groups showed good attitudes toward the task as well as effective thinking skills during working with their missions, those two factors affecting the creation and elaboration of appropriate problem spaces and resulting in their success. In the other hands, 'Low A' groups did not 
show good attitudes toward the task nor effective thinking skills, even though they were all identified as gifted students. This result implies that to be a good problem solver, it is essential to have good attitudes toward the task as well as effective thinking skills. We need to encourage students to experience successes through solving small challenge problems to develop good attitudes toward the problem in science class. We also need to develop curriculum in interdisciplinary science contexts to motivate students and develop thinking skills so that students can feel it is useful to solve their problems in everyday life or in the future.

\section{Acknowledgments}

This work was supported by the Korea Research Foundation Grant by the Korean Government (KRF2006-214-B00001).

\section{References}

Ausubel, D.P., 1968, Educational psychology: A cognitive view. Holt, Rinehart and Winston, NY, USA, $685 \mathrm{p}$.

Costa, A.L., 2003, The habit of skillful thinking, In Colangelo, N. and Davis, G.A. (eds.), Handbook of gifted education. Pearson Education, 325-334.

Dhillon, A.S., 1998, Individual differences within problemsolving strategies used in Physics. Science Education, $32,379-405$.

Gick, M.L., 1986, Problem solving strategies. Educational psychologist, 21, 99-120.
Goldschmidt, G., 1997, Capturing indeterminism: Representation in the design problem space. Design Studies, 18, 441-455.

Mayer, R., 1983, Thinking, problem solving, cognition. Freeman, NY, USA, $426 \mathrm{p}$.

Minstrell, J., 1989, Teaching science for understanding. In Resnick, L.B. and Klopfer, L.E. (eds), Toward the thinking curriculum: Current Cognitive Research. Association for Supervision and Curriculum Development, VA, USA, 129-149.

Pizzini, E.L., Shepardson, D.P., and Abell, S.K., 1989, A rationale for and the development of a problem solving model of instruction in science education. Science Education, 73, 523-534.

Rosebery, A.S., Warren, B., and Conant, F.R., 1992, Appropriating scientific discourse: Findings from language minority classrooms. The Journal of the Learning Sciences, 2, 61-94.

Schoenfeld, A., 1983, Beyond the purely cognitive: Beliefs, social cognitions and metacognitions as driving forces in intellectual performance. Cognitive Science, 7, 329363.

Sternberg, R.J., 1985, Critical thinking: Its nature, measurement, and improvement. In Link, F.R. (eds.), Essays on the Intellect. Association for Supervision and Curriculum development, VA, USA, 45-65.

Thomson, N. and Stewart, J., 2003, Genetics inquiry: Strategies and knowledge geneticists use in solving transmission genetic problems. Science Education, 87, 161-180.

Voss, J.F., Greene, T.R., Post, T.A., and Penner, B.C., 1983, Problem solving skill in the social sciences. In Bower, G. (ed.), The psychology of learning and motivation 17. Academic Press, 165-213.

Lego League Homepage, First Lego League, www.firstlegoleague.org (retrieved by October 12, 2008) 